\title{
Internationalization in U.S. universities: history, philosophy, practice, and future
}

\author{
Internacionalização em universidades dos EUA: história, filosofia, prática e futuro \\ Internacionalización en universidades de EE.UU: história, filosofía, práctica y futuro
}

\author{
MARILIA MOROSINI* \\ PATRICIA SOMERS** \\ ARINDA RODRIGUEZ ${ }^{* * *}$ \\ JANET SOLIS RODRIGUEZ ${ }^{* * * *}$
}

\begin{abstract}
In response to the global economy, universities around the world have increased internationalization efforts. This article focuses on internationalization in U. S. universities, discussing the history, presenting models and examples, reviewing the extent of internationalization on U.S. campuses. We end with a discussion on the rationales, the political realities of the new nationalism, the competition among Western universities for rankings that emphasizes high-profile internationalization, the current political questions affecting internationalization and the future of the field. While our focus is on the United States, many of the concepts and theories we discuss apply to other countries as well.
\end{abstract}

Keywords: Internationalization of Higher Education. Models of Internationalization of Higher Education. Trends in the Internationalization of Higher Education.

\section{RESUMO}

Como resposta à economia global, as universidades ao redor do mundo vêm incrementando seus esforços para se internacionalizaram. Este artigo tem como foco a internacionalização de universidades dos Estados Unidos discutindo a história, apresentando modelos e exemplos e examinando a presença da internacionalização no campus americano. Concluímos com a discussão sobre as racionalidades, as realidades políticas do novo nacionalismo, as argumentações acadêmicas contra as universidades do ocidente que enfatizam os altos perfis internacionais, as atuais questões políticas que afetam a internacionalização e o futuro do campo. Apesar do foco deste trabalho ser os Estados Unidos, muito dos conceitos e teorias discutidas podem ser aplicados para outros países.

Palavras-chave: Internacionalização da Educação Superior. Modelos de Internacionalização da Educação Superior. Tendências da Internacionalização da Educação Superior.

\section{RESUMEN}

En respuesta a la economía global, las universidades de todo el mundo han aumentado los esfuerzos de internacionalización. Este artículo se centra en la internacionalización en las universidades de los Estados Unidos, analiza la historia, presenta modelos y ejemplos, revisa el alcance de la internacionalización en los campus de los EE. UU. Terminamos con una discusión sobre los fundamentos, las realidades políticas del nuevo nacionalismo, las argumentaciones académicas entre las universidades occidentales que enfatiza la internacionalización de alto perfil, las cuestiones políticas actuales que afectan la internacionalización y el futuro del campo. Si bien nuestro enfoque se centra en los Estados Unidos, muchos de los conceptos y teorías que discutimos se aplican también a otros países. Palabras clave: Internacionalización de la Educación Superior. Modelos de Internacionalización de la Educación Superior. Tendencias de la Internacionalización de la Educación Superior.

\footnotetext{
* Professora titular. Pesquisadora 1aㅡ CNPq. Coordenadora CEES - Centro de Estudos em Educação Superiro/PUCRS. Coordenadora RIES - Rede Sulbrasileira de Investigadores da Educação Superior.E-mail: <marilia.morosini@pucrs.com.br>.

** Bacharel em Espanhol pela Michigan State University. Mestrado em Português pela University of Illinois at Urbana-Champaign. Doutorado em Educational Administration (Higher Education Specialization), Universityof New Orleans.E-mail: <pasomers@mail.utexas.edu>.

*** Bacharel em Aprendizado Aplicado e Desenvolvimento, com Certificação Bilingue Geralista. Atualmente cursando um mestrado em Políticas e Planejamento Educacional em Liderança e Política Educacional.E-mail: <aerodriguez11@utexas.edu>.

**** Bacharel em Belas Artes em Estudos de Teatro da Universidade do Texas em Austin. Cursa mestrado em Liderança e Política Educacional na Universidade do Texas em Austin.E-mail: <janets@utmail.utexas.edu>.
} 


\section{INTRODUCTION}

While internationalization of higher education in the United States has a long history, as the world economy globalized businesses recognized that colleges and universities needed to better prepare graduates to work in the New Economy. The International Monetary Fund (IMF) (2000) recognizes four elements of globalization - trade, migration, capital and investments, and the production and dissemination of knowledge. Clearly, higher education is recognized in this definition. Daly (1999) provides a definition for educators to embrace, "globalisation refers to global economic integration of many formerly national economies into one global economy, mainly by free trade... It is the effective erasure of national boundaries for economic purposes" (para. 1). Daly describes internationalization as "the increasing importance of international trade, international relations, treaties, alliances... the basic unit remains the nation" (para. 1).

The scholarly literature uses a variety of terms such as globalization, internationalization, transnationalism, multi-nationalism, binationalism, internationally recognized, and world class interchangeably to describe this process (KNIGHT, 2015, p. 107). Because of the turn towards nationalism in many countries, the term we prefer at this moment in time is inter-nationalization among countries and not the erasure of boundaries.

This article reviews the history of internationalization, presents models and examples of internationalization, summarizes the extent of internationalization on U.S. campuses, discusses the sea change in internationalization produced by the new nationalism, critiques the competition among Western universities for world rankings that emphasizes high-profile internationalization, and analyzes both the current political questions affecting internationalization and the future of the field. While our focus is on the United States, many of the concepts and theories we discuss apply to other countries as well.

\section{HISTORY OF INTERNATIONALIZATION IN U.S.}

The history of internationalization in U.S. universities has varied from almost total isolationism to approaching globalization. While efforts for internationalization were actively being developed in European nations, the United States' first involvement with globalization came in the $19^{\text {th }}$ century. The first international student in the U.S., John Diomatari of Greece was admitted to the University of Georgia and graduated in 1835. He returned to Greece and served as the U.S. Consul in Athens, Greece (LEE, 2012).
The $20^{\text {th }}$ century was marked by the monumental growth of student and faculty exchange programs, the formation of national groups promoting internationalization, temporary downturns in internationalization due to economic crises or wars, and expanded funding. As World War I neared an end, "American colleges, religious groups, and peacepromoting organizations started to explore creative ways to inspire their students to learn more about the world outside of U.S. borders" (LEE, 2012, para. 17). These groups believed that with international exchange, nations would understand each other better, leading to the possibility of lasting peace between nations, and cultivating better communications. Nobel Prize Winners Nicholas Murray Butler and Stephen Duggen founded the Institute of International Education (IIE) in 1919. The group encouraged students to travel abroad, created opportunities for foreign students to study in America, and helped establish student visas through the Immigration Act of 1921. In 1922, IIE initiated the first reciprocal exchange between the U.S. and Czechoslovakia.

World War II slowed the development of academic exchange. However, after the war, the Fulbright Program was created by legislation initiated by Senator J. William Fulbright (FULBRIGHT, 2017). It was the first federal support of exchange of faculty and students (both incoming and outgoing). Currently, the Fulbright Program includes grants for student and faculty exchanges in 160 countries and has local Fulbright Commissions in about 50 countries. Funding comes in the form of money from the U.S. Congress, the governments of participating countries, foundations, businesses, and universities. More than 360,000 scholars have participated in Fulbright programs.

As part of the International Opportunity Act of 2000, the Department of State created the Benjamin A. Gilman International Scholarship (GILMAN, 2017) in response to the critique that few first-generation and low-income college students had access to international exchange programs. The Gilman Scholarship provides grants for low-income students to enable them to study or intern abroad.

Following the world-wide recession of 2008, study abroad slowed. The National Association of Foreign Student Advisers (2017) reported that in the 2014-2015 academic year, just over 1.5 percent of all U.S. students had studied abroad for credit. Goucher College in Maryland and Soka University of America in California are the only colleges that require all undergraduates to study abroad (FRIEDMAN, 2017).

In January 2014, 100,000 Strong in the Americas was launched and according to the U.S. Department of State has been "expanding study abroad opportunities for students, our future leaders and innovators, strengthen[ing] 
bi-national relations and better prepar[ing] young people for the $21^{\text {st }}$ century global workforce." The vision of 100,000 Strong in the Americas is to create leaders who are internationally-aware and cross-culturally adept to reach across borders (100,000 STRONG, 2017).

While many advances have been made in international exchanges, there are still many challenges. Two key questions are increasing the number of participating undergraduate and graduate students and expanding access to international study and internships for lowincome and first-generation college students. Another challenge is the rise of nationalism and the decline of globalization; however, internationalization of higher education has successfully dealt with these problems in the past.

\section{STATE OF INTERNATIONALIZATION IN U.S.}

The American Council on Education (2017) has surveyed U.S. universities about their level of international activity every three years since 2001. Based on this research, ACE developed a six-part, comprehensive model for internationalization which includes institutional commitment, structure, curriculum, faculty policies, student mobility, and collaboration/ partnerships. ACE recommends that all six are necessary for internationalization, but the exact mix of activities depends on the circumstances of each university. For our purposes, we summarize four of the elements from the 2016 survey: institutional commitment, curriculum, student mobility, and collaboration/partnerships. A total of 1,164 institutions responded to the 2016 survey and the answers were weighted to adjust for the response rate. The data were stratified by institutional type (doctoral, Master's, baccalaureate, and associate) to provide more detail (AMERICAN COUNCIL ON EDUCATION, 2017).

\section{Institutional Commitment}

As the demands for internationalization increased, institutions responded in various ways. According to the American Council on Education's (ACE) mapping survey of 2016 (2017), higher education institutions (HEIs) have articulated their commitment to internationalization through their mission statements, strategic plans, and their financial support for internationalization programs (p. 1). Forty-nine percent had mission statements that directly referred to internationalization or related activities, while 47 percent of HEIs included internationalization or related activities in their strategic plans. Even though 27 percent of HEIs had separate strategic plans that addressed institution-wide internationalization, more institutions have implemented a campus-wide task force for promoting internationalization. HEIs also increased their financial support for internationalization by proactively engaging in fundraising campaigns and allocating more internal funding towards internationalization efforts (2017, p. 7-10).

\section{Curriculum}

In 2016, curriculum internationalization initiatives increased, including efforts at the departmental/program, college, and institutional levels. One component of curriculum internationalization for colleges and universities was concentrations or certificates. The most common discipline for these options was business, but growth in all disciplines were reported except physical and natural sciences. Seventeen percent of institutions offered broader-based programs open to students regardless of major. Finally, technology played a principal role in internationalizing curricular content (American Council of Education, 2017, p. 32-38).

\section{Collaboration and Partnerships}

The institutions were asked how they engaged with international partners. Of all participants, 73 percent worked directly with foreign universities and 34 percent paired with non-governmental organizations (NGOs). Doctoral universities were most likely to collaborate with other universities and the top seven countries for exchanges were Australia, Brazil, China, France, Germany, India and Mexico. The top countries targeted for expanded programs include China, India, Brazil, Mexico, Vietnam and South Korea. Of the doctoral institutions, 58 percent had dual or joint degree programs.

ACE suggested several good practices for partnerships, transparency and accountability, faculty and staff engagement, quality assurance, strategic planning and the role of institutional leadership, cultural awareness, access and equity, institutional and human capacity building, and ethical dilemmas and "negotiated space." (p.33)

\section{Student Mobility}

Overall, 47 percent of the institutions had an international student recruiting plan, ranging from 33 percent at Associate-degree-granting institutions to 75 percent at doctoral universities. Of those with plans, 83 percent had yearly targets for recruiting international students and 48 percent had geographic goals. The top 5 countries for recruiting were Brazil, China, India, Mexico and Saudi Arabia (p. 25-32).

Institutions were queried if there was an increase in U.S. student participation in study abroad. The average for all institutions was 45 percent, although doctoral (73 percent) and Master's (65 percent) universities were 
more likely to have an increase. At doctoral universities, international internships, service abroad, and research abroad participants all increased. One-fifth of all universities had goals for study abroad and they ranged from 1 percent to 100 percent (p. 25-32).

The ACE survey (2017) provides a wealth of data on the breadth and scope of internationalization in U.S. universities. One key finding was that, "In-house models dominate when it comes to resources for internationalization and the management of activities and programs. However, a notable proportion of institutions are also engaging with outside entities (third-party providers, funders, and international partners) to further support and supplement internal efforts" (p.6). This conclusion demonstrates the emphasis on home-grown programs with collaboration with associations of universities and other specialized groups.

\section{INTERNATIONALIZATION TYPOLOGY}

Is there a typology that reflects internationalization in various countries? The terms transnational, multinational, global, binational, "internationally recognized," and "world class" are used frequently in the literature (KNIGHT, 2015, p. 107). Knight points out the dilemmas of these definitions,

Many [educators] would point to the international and intercultural make-up of their student body and faculty/staff. Others would refer to their off-campus research and teaching centers in different parts of the world. Some would refer to the international and intercultural dimension of their institution's mission and goals, whereas others would specifically describe their efforts to internationalize academic programs and research initiatives (p. 108).

In response to this dilemma, Knight proposes three typologies or generic models of university internationalization: classical, satellite, and co-founded.

The classical model describes collaboration with various partners (universities, research centers, nongovernmental organizations, and government agencies, to name a few). The activities include student and faculty mobility (exchange programs), joint programs, research collaboration, professional development, and grantseeking. While the focus is academic, some collaborations seek status or pecuniary returns. Knight suggests that the classical model is most popular because it allows the partners to choose the nature and extent of their collaboration depending upon resources and priorities. She also identifies this model as the "first generation" of international programs.
Second is the satellite model using "satellite research centers, branch campuses, alumni contact offices, [for] recruitment of students and professors... [and also] fundraising" (p. 110-111). Knight acknowledges "satellite" as a broad, generic term. The main feature of the model is a "strategically planned and developed set of activities" (p. 111). One commonly used term for the satellite model is "international branch campuses" (IBCs). The American Council on Education (2017) reports the top exporters of IBCs are the U.S. (77), England (38), and France (28) while the top "importing" countries are China (32) and United Arab Emirates (32).

Third is the co-founded model, in which an independent university is licensed in another country by a sponsoring university. This is the third generation of internationalization. Knight explains, "While each example is slightly different, a key common element is that academic partners from different countries have been deeply involved in the establishment of the new institution" (p.112). Knight is careful to point out that the three models are very generic and there is not a strict list of activities for each.

\section{ANALYSIS OF MODELS}

In this section we present and discuss the three models and provide examples of U.S. universities that fit the classifications.

\section{Classical Model}

Founded in 1831 in Granville, Ohio, Denison University (DU) is one of the earliest institutions to be established in the "Northwest Territory" of the United States (Denison University, 2017). DU is a liberal arts college that offers three degrees: Bachelor of Arts, Bachelor of Science, and Bachelor of Fine Arts. About 2,250 students are enrolled; 7.6 percent are international students; 33 percent are designated multicultural (including international students) and 80 percent study abroad.

Denison University students can participate in 180 off-campus/study abroad programs in 68 countries. DU is a long-standing member of the Great Lakes Colleges Association, a consortium of thirteen private liberal arts colleges located in Indiana, Michigan, Ohio and Pennsylvania. GLCA created GLAA, "a multilateral partnership of American style liberal arts institutions with the goal of supporting excellence in liberal arts education on a transnational basis" (Denison University, 2016, para. 5). GLAA awarded Denison University a grant to enhance internationalization efforts. DU's initiative is the Internationalization Innovation Fund which will finance three projects: "a workshop on Internationalization and 
the Liberal Arts; monies to help maximize study abroad participation; and integrate students' study abroad experiences across the curriculum" (Denison University Blog, 2017). GLCA's Global Crossroads Initiative is sponsored by a grant from the Andrew W. Mellon Foundation.

\section{South Puget Sound Community College}

South Puget Sound Community College was established in 1962 by Olympia School District as the Olympia Vocational Technical Institute (OVTI) and achieved community college status in 1967. By 1988, the college separated from the School District and changed its name to South Puget Sound Community College (South Puget Sound Community College, 2017) (SPSCC).

Currently, SPCC offers an associate's degree which is transferable to most four-year colleges as well as corporate training, continuing education, and adult education. Although internationalization is not explicitly listed in the SPSCC mission statement, internationalization efforts are evident through the college's International Transfer and Study Abroad Programs. The International Transfer program allows SPSCC students to transfer their associate's degree into bachelor's programs at institutions such as The American Business School of Paris, Cork Institute of Technology, Goldsmiths, University of London, Otago Polytechnic (New Zealand) and University of Otago (New Zealand). Using the classical model, South Puget Sound Community College, has promoted internationalization and increased study abroad opportunities for its students. These student mobility programs are available in 8 countries in North America, Europe, Asia, and Oceania.

The College is a member of the Community Colleges for International Development (CCID) that seeks to promote globally engaged learning environments for community colleges. (CCID, 2017) In addition, SPSCC is a member of the Washington Community College Consortium for Study Abroad (WCCCSA). WCCCSA sponsors short- and long-term study abroad programs for community college students.

\section{Texas State University}

Texas State University was established in 1903 as Southwest Texas State Normal School (STSNS), a small teacher preparation institution. Over time, STSNS transformed into Texas State University, currently designated as an Emerging Research University. Texas State University serves about 38,694 students and offers 98 bachelor's, 91 master's, and 13 doctoral degree programs.

The international division's mission statement declares a commitment to "enhance the university's international profile and guide the strategic direction for comprehensive internationalization by overseeing international outreach, global engagement and the services provided by the International Office, the Study Abroad Office, and the Texas State Intensive English program" (TEXAS STATE UNIVERSITY, 2017). TSU participates in the American International Recruitment Council (AIRC), which certifies organizations that recruit international students such as College Study U.S., Disha Consultants, IAE Global, IDP, IEC, Pac-Asia and UStudy.

Study abroad opportunities at TSU include facultyled programs, affiliated programs, exchange programs, and non-affiliated programs. The study abroad mission is to "support the comprehensive internationalization plan of Texas State University by providing safe, accessible, academically rigorous, geographically diverse, and culturally enriching global education experiences" (TEXAS STATE UNIVERSITY, 2017). International exchange programs are available in 38 countries in Asia, Canada, Europe, and Latin America.

Knight asserts that the classical model is the most common approach to internationalization by universities around the world because of its flexibility, adaptability, and lower cost. We agree with her assessment regarding small and medium-sized U.S. universities. We profiled three types of universities (private, public, two-year) from different parts of the country to illustrate that using existing resources and collaborations, almost any institution can bring affordable international programs to campus.

\section{Satellite model}

A university with three or more overseas satellite campuses or offices is often referred to as an international networked university. For example, New York University calls itself a "Global Networked University" with campuses in Shanghai, Abu Dhabi, and New York and research centers in Accra, Berlin, Buenos Aires, Florence, London, Madrid, Paris, Prague, Sidney, Tel Aviv, and Washington, D.C. (New York University, 2017). This global network "offers NYU faculty an unparalleled range of international and multi-disciplinary opportunities for research, teaching, and scholarly collaboration" (New York University, 2017). Options available for New York faculty are joint professorships between the faculty in New York, Abu Dhabi, or Shanghai, affiliated teaching appointments at NYU Abu Dhabi and NYU Shanghai, and short-term housing in New York for visiting international collaborators.

Each year more than 3,000 NYU undergraduate students study abroad. The choices include undergraduate semester or academic year abroad, graduate degree programs, student exchange opportunities, discipline- 
specific programs, January Term Abroad, global engagement symposium, and freshmen abroad programs. Both credit-bearing and not-for credit offerings are possible, but both options are not available at all sites. In addition to courses, students may take a formal internship or set up an informal internship. Internships in Berlin, Buenos Aires, Madrid, and Paris are in the local language. Courses and internships are available in other languages as well: Arabic, Chinese, Czech, French, German, Hebrew, Italian, Polish, Russian, Spanish, and Twi.

NYU "is home to the highest number of international students in the United States with over 17,000 international students and scholars from over 140 different countries" (NEW YORK UNIVERSITY, 2017). IIE's 2016 Open Doors Report ranked NYU, "number 1 for the number of students who study" in the United States (NYU GLOBAL PROGRAM BROCHURE, 2017).

As an example of the possibilities, NYU Abu Dhabi offers over 600 courses per year, has small classes that average 12 students, has over 1,100 students from more than 110 countries, and a choice of 600 courses in 22 majors in the sciences, social sciences, humanities, arts, and engineering.

\section{Co-founded model}

Knight's co-founded model (CFM) is the most involved and complex. "These are independent institutions ... licensed by the host country but developed through international collaboration" (KNIGHT, 2014). The myriad of challenges of the CFM include staffing, accreditation, host country language(s), laws, customs, awarding of qualifications, and governance. Here we discuss one cofounded university, the Community College of Qatar.

Houston Community College (HCC) is an unlikely partner for a co-founded college in the Middle East. However, a review of the city statistics portrays a cosmopolitan international port city with thriving international businesses and trade. The estimated population in 2016 was about $2,300,000$. An estimated 1.1 million residents were born outside of the U.S. Twothirds of those were born in Latin America. Houston has the third largest concentration of foreign consulates in the U.S. The port of Houston leads the country in international tonnage handled. The major industries are international trade, science, medicine, space, technology, education, and research.

In 2010, the Houston Community College System co-founded the Community College of Qatar (CCQ) supported by the Qatar Foundation. The CCQ was envisioned as providing remediation for students planning to attend a four-year college, credentialing, and the awarding of Associate's degrees. HCC's operational services included devising a curriculum like that of their home campus, consulting on student recruiting and admission, developing a plan to obtain accreditation from the Southern Association of Colleges and Schools (SACS), assisting in library development, establishing an information technology system for CCQ, staffing the college, and awarding degrees and certificates. The West Bay Campus (for men) of QCC was opened in 2010 and the C-Ring (women's) campus was opened four months later. Since HCC awarded the degrees, they were recognized as being from a college accredited by SACS.

In the five-year collaboration between HCC and CCQ, there were many challenges, first was the meshing of two large bureaucracies with their own norms, cultures, and languages. Second were many political issues: gender equality, religious freedom, and satisfying elected officials back in Houston. The third issue was academic freedom for faculty in teaching and research, and for educational and research materials. Fourth were the complicated logistics of housing, travel, and moving family belongings through customs. A fifth issue was the rules for and amount of control for students, faculty, and staff. These issues and their enforcement were covered by contracts negotiated over time through two public bureaucracies, two very different cultures, and using two languages.

The collaboration was, finally, beneficial in several ways. HCC established the first community college in the country, which now enrolls over 4,300 students. A greater cross-cultural awareness was gained by all from the college who participated - either in Houston or Qatar. HCC had a net profit from the five-year project of \$US1, 500,000 and provided employment for over 80 families. CCQ was turned over to the Qatari government in 2015. Because of the reputational boost the project gave to $\mathrm{HCC}$, the college has had several inquiries about starting community colleges in other countries.

\section{Discussion}

We have raised several issues worthy of more discussion. These include the philosophy, the motivation, the new nationalization, and world rankings of universities.

\section{Motivation to internationalize}

Seeber, Cattaneo, Huisman, and Paleari (2016) studied the internationalization motivations of over 400 European universities. Using the results of the International Association of Universities survey (EGRONPOLAK \& HUDSON, 2014) and two datasets with organizational data from European universities, they developed a multi-level theoretical model that considered macro factors (global and national contexts), meso factors (higher education institutional factors), and micro factors 
(actors who influenced internationalization decisions). Seeber et al. developed and tested nine rationales for internationalization,

increased international awareness of/deeper engagements with global issues by students, enhanced internationalization of the curriculum, improved quality of teaching and learning, strengthened institutional research and knowledge production capacity, enhanced prestige/profile for the university, opportunity to benchmark/compare institutional performance... international good practice, enhance international cooperation and capacity building, increased international networking by faculty and researchers, and increased/diversified revenue generation (p. 688) (emphasis is ours).

The researchers categorized their data as "relatively robust" (p.698). They organized their findings by environmental, organizational and intra-organizational factors. For the environmental factors, Eastern European countries adopted the teaching rationale while United Kingdom (U.K.) and German HEIs (higher education institutions) were less likely to internationalize to improve teaching. Both U.K. and Irish universities were much more likely to choose the revenue rationale. Universities that were listed in the global rankings were more likely to choose the prestige or reputation rationales for internationalizing.

As for the organizational factors, for-profit universities were more likely to adopt a revenue rationale for internationalization. Research-intensive universities were more likely to use a production of knowledge rationale rather than teaching to justify internationalization. Teaching-intensive universities were more likely to focus on the benefits of an international curriculum for their students and not improved teaching.

Finally, the intra-organizational factors consider the influence of local actors (faculty, staff, students and administrators). The revenue generation rationale was negatively associated with student involvement. The networking rationale occurred more when faculty influence was strong. Where middle managers had more influence, the rationale for internationalization was more likely to be institutional cooperation.

To apply this research to universities, we revisit the universities described in the earlier part of this article. Denison University, the small private liberal arts college in the Midwest, is likely pursuing internationalization to give students more opportunities to engage with global issues, enhance the curriculum, and improve the quality of teaching and learning. Because of the low faculty-student ratio and faculty interest in area studies, the institution is likely more focused on student and faculty experiences than other objectives like revenue production. Indeed, Denison collaborates with other universities to sponsor student and faculty exchange programs.

Texas State University (TSU), the large public university located in central Texas, is considered a "striving university" (GONZALES, MARTINEZ, \& ORDU, 2014). This means that TSU is in the process of becoming recognized as an elite research university. Therefore, their rationales for internationalization are connected to this goal. Networking by faculty and researchers, enhanced prestige, and increased knowledge production are likely more important than teaching, student learning, and revenue production rationales.

Because of South Puget Sound Community College's location on the Pacific Rim, it has strong support from the local business community to internationalize. One rationale is to provide students, community members, and local businesses with a greater understanding of global issues, particularly as applied to global trade. Enhanced internationalization strengthens the curriculum and the quality of teaching and learning. However, SPSCC also generates revenue from exchange programs for visitors.

New York University's Global Network seems to pursue several rationales for internationalization. They seek a deeper knowledge of global issues for their students and a more global and flexible curriculum. NYU provides extensive faculty exchange opportunities which allow faculty and researchers to network across campuses. Organizationally, the Global Network increases knowledge production and enhances prestige for the university. In addition, the Network generates income. The rationales for internationalization at NYU are much more complex than the other four universities.

Finally, Houston Community College has multiple, but less complex rationales for their co-founded campuses. The primary rationale is revenue generation for the university. HCC has a successful model of training and graduating low-income and first-generation college students. Moreover, HCC filled a gap in the Education City offerings - in terms of associate's degrees, skilled training, and remediation for college-bound students. At the same time, the college provided employment and an international engagement for faculty members.

Seeber et al. provide insights into the motives for universities to internationalize and the actors involved in the process. As part of the strategic planning process, universities wishing to expand their international offerings can use the nine rationales to develop and implement strategic goals. While the models and philosophies of internationalization are useful typologies, the Seeber et al. research is much more valuable when implementing programs at the institutional level. 


\section{Internationalization and world rankings}

Universities are being pressured by policy-makers, constituents, politicians, students and their families to compete on the global stage for reputation, status, wealth, and power. What better way to demonstrate the quality of a university's brand than a high-visibility satellite, branch, or co-founded university? The larger the effort, the better for a university's reputation. While a few campuses abroad fared badly and closed, most have high visibility and enhance the reputation of the university.

World-wide rankings (also called league tables) have been controversial since they were launched in the 1980s. As Seeber et al. found, the primary internationalization rationale for many universities is to enhance their reputation and rankings. This "race to the top" encourages universities to spend money on the programs that most directly affect ratings. An international branch campus or co-founded university is an example of a high-cost item that can influence rankings.

There are three major world rankings. Simon Marginson, Director of the Centre for Global Higher Education at the University of London gave the history of three (WORLD UNIVERSITY NEWS, 2017). The Academic Rankings of World Universities (ARWU) (http://www.shanghairanking.com/ARWU2016.html) was created in Shanghai in 2003. He said, "[AWRU] was a benchmarking exercise to demonstrate the gap in science between China and America... it focused just on research and its indicators represented key features of U.S. research universities" (2017, para. 14). In 2004, The Times [of London] Higher Education Ranking was developed (https://www.timeshighereducation.com/ world-university-rankings). Marginson said The Times sought "a ranking that would differ from the ARWU, service the global student market in education, and position British universities well" (2017, para. 15). The final ranking is the British QS (https://www. topuniversities.com/). Marginson points to the QS's canny business model, in which the rankings are a loss leader because, "the company runs a global business in consulting conferences, and ranking-related services" (para. 16).

Most rankings - whether global, national, regional, or local have two major methodological issues. First is the use of multiple indicators that are then compressed into a single statistic. The second issue is the weighting of the indicators, which Marginson contends could be capricious. The creators of rankings systems develop a "best university" rating based on data that combine several indicators. However, the indicators are different for each ranking system and qualitative and quantitative data are mixed together. Further, proxy rankings like faculty/ student ratios and books in the library can be substituted for the more difficult-to-measure academic outcomes. Marginson advocates more transparent calculations that have separate indicators and many rankings based on specific indicators. He said that the overall rating for some rankings is nothing more than "junk" since "[they are based on] multi-indicator rankings that use arbitrary weights and freely mix objective and subjective data in an incoherent manner... [but individual indicators can be] very valuable" (para. 33-34).

Ironically, the Times Higher Education World University Rankings of 2018 released what they termed the "international pillar" list. Oddly, twenty of the top fifty universities on this list were from the U.K. and none were from the U.S. While not transparent in the criteria and weighting, the Times seems to rate highly universities with large numbers of international students, faculty, and staff (at some universities over 40 percent of each category); the liberal availability of scholarships for international students; the internationally strategic and multi-cultural location of the university; the number of languages of instruction; study abroad programs; partnerships with multi-national companies and non-governmental organizations; and research collaborations with universities in other countries. The top 10 universities for the international pillar are the University of Luxembourg, Qatar University, University of Hong Kong, University of Sharjah, Ėcole Polytechnique Fédérale de Lausanne, University of Lausanne, University of Macau, University of Geneva, ETH Zurich - Swiss Federal Institute of Technology Zurich, Khalifa University, and Alfaisal University. Only three of these universities are ranked in the Top 50, while the others rank as high as the 501-600 tier. This demonstrates how easily the lists can be manipulated and argues for the use of very transparent criteria and weights as well as separate rankings by indicator.

\section{Internationalization and hegemony}

The philosophy of internationalization of universities has until recently assumed the North Atlantic notions about universities, privileging American and European models over those from other countries. This includes the hegemony of Western philosophy, culture, and history, and the use of Western models of higher education. Even the nascent exchanges in U.S. higher education in the $19^{\text {th }}$ and early $20^{\text {th }}$ century focused on classical languages, culture, and history. On occasion and funded by wealthy patrons or scientific groups, faculty led natural history expeditions to "other" countries in Africa, Asia, and Latin America which focused on fauna, flora, culture, language, and archeological ruins in "foreign countries." 
After World War II, the U.S. had a multi-pronged approach to exchanges. Universities were encouraged to recruit bright students from less developed countries to study in the U.S. and return to their home countries to research, teach, establish American-style universities, and assume leadership positions. Through the U.S. Agency for International Development (USAID), scientists from universities and labs were dispatched to help in the agricultural, industrial, and technological expansion of less-developed countries. Finally, the Fulbright Programs was established to develop mutual understanding between peoples of various countries (FULBRIGHT, 2017).

Part of the Fulbright program was to train bright graduate students from less developed countries who would return to their home countries to develop a research and technological infrastructure and strengthen fledging universities abroad. Of course, universities and businesses had no reservations about hiring the best of these students to stay in America. The foreign brain drain was exacerbated by the Immigration Act of 1971 which for the first time provided preference to work visa applicants who had technical and professional skills that the U.S. needed regardless of country of origin.

The Western philosophy of internationalization shifted in the 1990s with the emergence of the global economy. As countries previously considered less developed emerged in the expanding economy, the economic dynamics between Western and other countries increased. A good example is the BRIC (Brazil, Russia, India, and China) countries which gained importance in the global economy as providers of less expensive goods and services. For at least a moment in time, Western universities sought to educate college students to function as global citizens. This training focused on the ability to work across borders with cultural sensitivity, appropriate language skills, and knowledge of global economics. However, the Great Recession of 2008 changed all this.

\section{The new nationalism}

The world-wide recession of 2008 slowed the growth of the global economy. Unemployment increased. Workers who considered themselves as global citizens just months earlier overnight became xenophobic rivals. Refugees and foreign workers were vilified. Some countries erected physical and other barriers to refugees and immigrants to prevent their participation in what had been an open economy.

With this new nationalism came a reduction in support for internationalization at all levels of society and an increase in political isolation. Rather than viewing the world as a global community, some countries withdrew politically and economically by escaping from trade agreements, refugee commitments, and other activities of the global economy. Emblematic of this rejection was Britain's flight from the European Community (Brexit). Since the production of knowledge is part of the global economy, this isolation slowed the internationalization of higher education. Internationalization has faced setbacks previously from wars, economic downturns, and political shifts and has eventually recovered.

The breadth and scope of internationalization in U.S. universities are wide ranging, however, the classical model with the emphasis on home-grown activities and wide collaboration with partners is still the most dominant model. In this current cycle of nationalism and xenophobia, internationalization faces an uncertain future - in the U.S. and other countries. However, history demonstrates that after periods of slow down due to economic or political cycles, internationalization returns stronger than ever.

\section{REFERENCES}

AMERICAN COUNCIL ON EDUCATION. Mapping internationalization on U.S. Campuses 2017 Edition. Available at: <http://www.acenet.edu/news-room/Documents/MappingInternationalization-2017.pdf > . Accessed: Sept. 27, 2017.

COMMUNITY COLLEGES FOR INTERNATIONAL DEVELOPMENT. About CCID. Available at: <https://www. ccidinc.org/about-us>. Accessed: Oct. 9, 2017.

DALY, H. E. Globalisation versus internationalization. 1999. Available at: <http://www.globalpolicy.org/component/content/ article/162/27995.html>. Accessed: Oct. 21, 2917.

EGRON-POLAK, E.; HUDSON, R. Internationalisation of higher education - growing expectations, fundamental values. Paris: International Association of Universities. 2014.

DENISON UNIVERSITY. Denison receives grant for global initiatives. Available at: <https://denison.edu/academics/ provost/wh/87410>. Accessed: Oct. 9, 2017.

DENISON UNIVERSITY. Global Learning/Off Campus Studies. Available at: <https://blogs.denison.edu/facultynews letter/2017/02/16/global-learning-off-campus-studiesfebruary-2017/>. Accessed: Oct. 9, 2017.

GILMAN SCHOLARSHIP PROGRAM. Benjamin A. Gilman International Scholarship Program. About. Available at: $<$ https:// www.iie.org/Programs/Gilman-Scholarship-Program>. Accessed: Oct. 9, 2017.

FRIEDMAN, Jordan. 10 Colleges Where Studying Abroad is Common. U.S. News \& World Report Higher Education, 27 June 2017. Available at: <https://www.usnews.com/education/ best-colleges/the-short-list-college/articles/2017-06-27/10colleges-where-studying-abroad-is-common>. Accessed: Oct. 9, 2017.

FULBRIGHT SCHOLAR PROGRAM. About Us. Council for International Exchange of Scholars. Available at: $<\mathrm{http}: / / \mathrm{www}$. cies.org/about-us>. Accessed: Oct. 9, 2017.

GONZALES, L.D.; MARTINEZ, E.; ORDU, C. Exploring faculty experiences in a striving university through the lens of academic capitalism. Studies in Higher Education, v. 39, n. 7, p. 1097-1115, 2014. 
INTERNATIONAL MONETARY FUND. Globalization threats or opportunities. IMF Publications, Washington, District of Columbia. 2000.

KNIGHT, J. What is an international university. In: GLASS, A. (Ed.). The state of higher education. Paris, France: Organisation for Economic Cooperation and Development. 2000. p. 139-143.

KNIGHT, Jane. International Universities: Misunderstandings and Emerging Models? Journal of Studies in International Education, v. 19 n. 2, p. 107-121. 2015.

LEE, Megan. The Complete History of Study Abroad. Go Overseas. 17 April 2012. Available at: <https://www. gooverseas.com/go-abroad-blog/history-study-abroad-part-1>. Accessed: Oct. 12, 2017.

NATIONAL ASSOCIATION OF FOREIGN STUDENT ADVISERS. Trends in U.S. Study Abroad. Available at: <http:// www.nafsa.org/Policy_and_Advocacy/Policy_Resources/ Policy_Trends_and_Data/Trends_in_U_S_Study_Abroad/ $>$. Accessed: Oct. 9, $20 \overline{017}$.

NEW YORK UNIVERSITY. Faculty in the Global Network. Available at: <https://www.nyu.edu/faculty/faculty-in-theglobal-network.html>. Accessed: Oct. 6, 2017.

NEW YORK UNIVERSITY. International Students. Available at: $<$ https://www.nyu.edu/students/communities-andgroups/international-students.html>. Accessed: Oct. 9, 2017.
NYU GLOBAL PROGRAM. NYU's Global Network A Guide For Visiting Students. Available at: $<$ https://issuu.com/ newyorkuniversity/docs/17gp_014_revfinal_genbrochebookiss>. Accessed: Oct. 9, 2017.

SEEBER, Marco; CATTANEO, M.; HUISMAN, J.; PALEARI, S. Why do higher education institutions internationalize? An investigation of the multilevel determinants of internationalization rationale. Higher Education, v. 72, p. 685-702. 2016.

SOUTH PUGET SOUND COMMUNITY COLLEGE. Available at: $<$ https://spscc.edu>. Accessed: Oct. 9, 2017.

TEXAS STATE UNIVERSITY. About. Available at: < http:// www.txstate.edu>. Accessed: Oct. 9, 2017.

Times Higher Education. World University Rankings 2018. Available at: <https://www.timeshighereducation. com/world-university-rankings-2018-top-performers-ourinternationalisation-pillar>. Accessed: Oct. 9, 2017.

U.S. DEPARTMENT OF STATE. 100,000 Strong in the Americas. Available at: <https://www.state.gov/p/wha/ rt/100k/>. Accessed Oct. 9, 2017.

UNIVERSITY WORLD NEWS. Overall outcomes of rankings are "junk", v. 478, Oct. 13, 2017. Available from: <http://www. Universityworldnews.com>. Accessed: Oct. 16, 2017.

Recebido em 30-08-2017. Aprovado em 01-12-2017. 